Expansion, Verlag Julius Klinkhardt, Bad Heilbrunn/OBB, 2003.

Heidemarie Kemnitz (1955-) jest docentem prywatnym w Instytucie Pedagogiki Ogólnej Uniwersytetu Humboldta. Autorka m.in.: Bildungsideen und Schullalltag im Revolutionsjahr, Baltmannsweiler 1999; Lehrerverein und Lehrerberuf im 19. Jahrhundert. Eine
Studie zum Verberuflichungsprozess der Lehrehrtätigkeit am Beispiel der Berlinischen Schullehrergesellschaft (1813-1892), Weinheim 1999.

3 Wśród autorów artykułów warto wskazać na badaczy znanych z publikacji dotyczacych historii edukacji m.in.: Christoph Luith, Heinz-Elmar Tenorth, czy wspomniany K.-P Horn.

\title{
Rola szkolnictwa łódzkiego w tworzeniu dziedzictwa kulturowego Łodzi w XX wieku. Tradycje i współczesność łódzkich szkół średnich, red. Tadeusz Jałmużna, Łódzkie Towarzystwo Naukowe, Lódź 2003, ss. 353
}

W kwietniu 2003 roku Łódzkie Towarzystwo Naukowe wydało pracę pt. „Rola szkolnictwa lódzkiego w tworzeniu dziedzictwa kulturowego Lodzi w XX wieku. Tradycje i współczesność łódzkich szkół średnich".

Pozycja składa się z trzech części, z których każda porusza inną przestrzeń działalności szkolnictwa lódzkiego i jego twórców. Również czasowo, jak sam tytuł wskazuje, książka obejmuje właściwie prawie cały wiek XX oraz pierwsze „chwile" wieku XXI.

Część pierwsza, opatrzona tytułem „Pozadydaktyczna działalność nauczycieli", zawiera sześć artykułów. Wśród nich poruszane są problemy tradycji w pedagogice ujęte jako problemy metodologiczne, zagadnienia dotyczace miejsca nauczycieli szkół średnich ogólnokształcących w społeczeństwie Polski międzywojennej, informacje na temat łódzkiej szkoły średniej w lokalnej prasie codziennej Drugiej Rzeczypospolitej, działalność Towarzystwa Nauczycieli Szkół Średnich i Wyższych w Łodzi w okresie międzywojennym, średnie szkoły ogólnokształcące dla mniejszości narodowych mieszkających w Łodzi w w/w okresie, czy innowacje pedagogiczne w szkołach średnich miasta Łódź w latach $1970-2000$.

W tej części interesujące jest zaprezentowane przez Wiesławę Leżańska stanowisko nauczycieli szkół średnich w Łodzi w okresie międzywojennym, którzy, starając się odcinać od wszelkich rozgrywek politycznych, popularyzowali wiedzę, integrowali grupy społeczne, kształtowali poczucie jedności narodowej. Autorka wskazuje jak bardzo ważna była praca wychowawców w warunkach odradzającej się państwowości polskiej, jak istotne było rozwijanie intelektualnych zdolności swoich wychowanków, ułatwianie adaptacji do nowych warunków życia i pracy, rozwijanie zainteresowań, ksztaltowanie poglądów. Pomimo stosunkowo niskiej stabilizacji zawodu nauczycielskiego w owym okresie, starali się oni wypełniać swe obowiązki z poświęceniem i odpowiedzialnością, co należycie przedstawia W. Leżańska.

Iwonna Michalska udowadnia w swej pracy, jak cennym źródłem poznania minionej rzeczywistości oświatowej sa czasopisma, a wśród nich zwłaszcza periodyki oświatowo-pedagogiczne i pedagogiczne wydawane przez władze szkolne, stowarzyszenia, związki nauczycielskie, organizacje społeczne, czy osoby prywatne. Autorka słusznie zwraca uwagę na istotę owych wydawnictw, w których odnotowywane są często rzeczy drobiazgowe, wydawałoby się nieistotne, których nie znajdziemy $w$ innych dokumentach czy kronikach. Informacje te jednak pozwalaja badaczowi „poczuć" klimat, jaki w badanej rzeczywistości miał miejsce, pozwalają mu zrozumieć wiele wydarzeń, które zamieszczone w dokumentach czy kronikach, często owych „emocji”, jakie im towarzyszyły, nie posiadaja.

Działalność Towarzystwa Nauczycieli Szkól Średnich i Wyższych w Łodzi w okresie międzywojennym zaprezentował Grzegorz Michalski, ukazując poważne zaangażowanie Towarzystwa w sprawy naukowe, zawodowe, kształcenia i dokształcania kadr pedagogicznych oraz problemy 
opieki wychowawczej nad młodzieżą szkolną. Autor słusznie ukazał poważną rolę, jaka organizacja ta odegrała w budowaniu szkolnictwa średniego owego okresu, a tym samym w tworzeniu dziedzictwa kulturowego Łodzi.

Istotne miejsce wśród szkół średnich w Łodzi w okresie Drugiej Rzeczypospolitej zajmuja szkoły mniejszości narodowych. Zagadnienie to zgłębił Krzysztof Baranowski, prezentujac dzialalność żydowskich i niemieckich szkół. Poruszony temat jest istotny zważywszy na fakt, iż w okresie międzywojennym Łódź byla drugim co do wielkości ośrodkjem ludności żydowskiej na ziemiach polskich, a także poważnym skupiskiem mniejszości niemieckiej w Polsce. Autor w pracy swej poprzez analizę działalności kolejnych szkół mniejszościowych, ukazuje istotna rolę, jaka odegrały one w życiu społecznym i kulturalnym Eodzi.

Innowacje pedagogiczne w łódzkich technicznych szkołach średnich w latach 1970-2000, to zagadnienie podjęte przez Janusza Moosa i Bożenę Zajac. Temat istotny, ponieważ łódzkie szkolnictwo zawodowe od wielu lat zajmuje ważne miejsce w skali kraju w zakresie organizowania i prowadzenia różnorodnych rozwiązań innowacyjnych. Autorzy pracy przedstawiaja nowatorska działalność pedagogiczna oraz wskazuja jej twórców na tle całego kraju.

„Nauczyciel w procesie dydaktyczno-wychowawczym", to temat drugiej części opracowania. Zawartych w nim jest osiemnaście artykułów, z których każdy przedstawia inną wybitną osobowość łódzkiego środowiska pedagogicznego, która poprzez swa wyjątkowa działalność wychowawcza $\mathrm{i}$ edukacyjna na trwałe wpisała się $w$ historię tego miasta.

Autorzy prac trafnie przedstawili nietuzinkowość każdej z prezentowanych osób, ukazując aktywność pedagogiczna, społeczna, naukowa, która często wpływała na dalsze losy środowiska, szkoły, czy samych wychowanków.

Trzecia część pracy pt. „Przeszłość i wspólczesność łódzkiego szkolnictwa średniego", to prezentacja kolejnych szkól średnich, jakie istniały oraz działaja w Łodzi obecnie.

Wśród materiałów zamieszczonych w tej części na uwage zasługuje praca przedstawiajaca działalność Prywatnego Gimnazjum Żeńskiego Zofii Pętkowskiej i Wiktorii Macińskiej w latach
1918-1939. Ewa Witkowska-Urban w artykule tym prezentuje istotną rolę, jaką szkoła odegrała w ówczesnym środowisku łódzkim.

Tadeusz Jalmużna w artykule swym ukazuje działalność Korespondencyjnego Gimnazjum i Liceum Związku Młodzieży Polskiej w Łodzi w latach 1948-1950. Porusza on tak istotny wówczas problem dostępności ogólnokształcącej szkoły średniej dla młodzieży wiejskiej, analizuje kolejne etapy funkcjonowania Korespondencyjnego Gimnazjum i Liceum, zgłębia zagadnienie działalności organizowanych przez Szkołę terenowych ośrodków dydaktycznych. Temat przedstawiony przez T. Jałmużnę zasługuje na uwage zwazywszy na fakt obecnej polityki oświatowej oraz tendencji w zakresie kształcenia ustawicznego i kształcenia na odległość, tzw. e-learning (nauczanie przez internet).

Edward Wieczorek przybliżył okoliczności powstania i działalności Salezjańskiej Szkoly Rzemiosł, zwracajac uwage na jej wspaniałe funkcjonowanie $w$ okresie międzywojennym, "powrót" po drugiej wojnie światowej oraz likwidacje w roku 1962. Jak słusznie wskazuje autor, duch owej Szkoły przetrwał wraz z patronem, sw. Janem Bosko, ponieważ trzydzieści lat po jej zamknięciu, została ona znowu reaktywowana jako Liceum i Gimnazjum Salezjańskie oraz Salezjańska Wyższa Szkoła Ekonomii i Zarządzania. Nadal, jak wskazuje E. Wieczorek, uczy i wychowuje w duchu swego wielkiego założyciela, św. Jana Bosko - przyjaciela dzieci i młodzieży.

W krajobraz i historię Łodzi wpisały się oraz cały czas się wpisuja licea opisane w kolejnych artykułach niniejszego opracowania. Są to: I Liceum Ogólnokształcące im. M. Kopernika, które zaprezentował w swej pracy Henryk Władysław Skorek, II Liceum Ogólnokształcące im. Gabriela Narutowicza w latach 1904 -2002, opisane przez Aleksandra Łynka, III Liceum Ogólnokształcące im. Tadeusza Kościuszki, ukazane przez Kazimierza Michalewskiego, IV Liceum Ogólnokształcące im. Emilii Sczanieckiej, autorstwa Izabeli Nowakowskiej, IX Liceum Ogólnokształcace opisane przez Zdzisława Ignaczaka i Andrzeja Kolasińskiego, XXVI Liceum Ogólnokształcące im. Krzysztofa Baczyńskiego ukazane w pracy Danuty Falak, XII Liceum Ogólnokształcące im. Stanisława Wyspiańskiego autorstwa Ewy Toś. 
Wszystkie te artykuły prezentuja kolejne etapy dzialalności w/w szkól, przedstawiaja ich osiaggnięcia, również pewne innowacje, które w szkołach realizowano $w$ przeszłości oraz te, które realizowane sq obecnie. Między innymi w I LO im. Kopernika do nowatorskich inicjatyw pedagogicznych należą autorskie programy klasy przyrodniczej i klasy matematycznej z poszerzonym programem historii i geografii. Szkoła ta została w kwietniu 2002 roku wyróżniona, na podstawie Uchwały Rady Miejskiej, odznaka ,Za zasługi dla miasta Łodzi".

Inny artykuł K. Michalewskiego pozwala czytelnikowi „poczuć ducha”, jaki przyświecal i przyświeca uczniom oraz nauczycielom III-ego LO w ich zmaganiach edukacyjnych, pedagogicznych i wychowawczych. Artykuł 6́w każe rzeczywiście wierzyć, że uczniowie „od wszystkich innych tę szkołę wola".
Wśród placówek edukacyjnych istniejących w Lodzi są też takie, które istnieja stosunkowo niedługo. Recenzowana pozycja również pozwala je poznać. Sa to między innymi XLI Liceum Ogólnokształcące zaprezentowane przez Krzysztofa Skrzypka oraz Społeczne Liceum Ogólnokształcace Towarzystwa Oświatowego „Szkoła 2001", ukazane w artykule Anny Szymczak. Autorzy prezentuja tutaj nowatorstwo owych szkól oraz ich klimat, już wyraźnie ,europejski".

Recenzowana praca wnosi cenny wkład w historiografię szkolnictwa średniego w Polsce i w Łodzi. Ukazuje ona dynamikę i nietuzinkowość tego szkolnictwa średniego oraz jego rolę we wzbogacaniu dziedzictwa kulturalnego Łodzi.

\section{Ryszard Ślęczka, Szkolnictwo zawodowe Krakowa w latach 1945 - 1961, Kraków 2003, ss. 168}

Książka Ryszarda Ślęczki pt.: Szkolnictwo zawodowe Krakowa w latach 1945 - 1961 zastuguje na uwagę, gdyż jej problematyka dotycząca fragmentu dziejów oświaty Krakowa, jakim jest szkolnictwo zawodowe w latach 1945 - 1961, nie została przedstawiona do tej pory w sposób pełny i całościowy. Opracowanie tematu szkolnictwa zawodowego jest tym ważniejsze, że polska tradycja szkolnictwa zawodowego „miała udział w kształtowaniu świadomości edukacyjnej społeczeństwa oraz wpływala na stosunki ekonomiczne, zwlaszcza w trudnych czasach zmian ustrojowych"1

Autor, posługując się metodą właściwą badaniom historycznym, wykorzystał różne źródła, dokonał ich wyboru, selekcji oraz poddał formalnej i rzeczowej krytyce, a także porównaniu i opracowaniu. Odwołal się w swojej pracy do materiałów archiwalnych, $m$. in.: danych zgromadzonych w Archiwum Akt Nowych w Warszawie, Archiwum Kuratorium Oświaty w Krakowie, Archiwum Państwowego w Krakowie, źródeł normatywnych, m. in.: Dzienniki Ustaw Rzeczypospolitej Polskiej, Dzienniki Urzędowe Kuratorium Oświaty i Wychowania w Krakowie. Dopelnie- niem natomiast jest przytoczenie faktów $\mathrm{z}$ literatury naukowej. R. Ślęczka dokonuje krytycznego przeglądu syntez i różnych artykułów na temat szkolnictwa zawodowego w Krakowie. Podkreśla wartość rozpraw $\mathrm{m}$. in.: C. Siwińskiego, M. Godlewskiego, Z. Wiatrowskiego, T. Nowackiego, J. Miąso, a także artykułów: S. Gawlika, H. Glowackiego i J. Platy dotyczących rozwoju szkolnictwa na Śląsku.

Książka została podzielona według kryterium problemowo-chronologicznego. Czasowo, obejmuje okres od zakończenia II wojny światowej do uchwalenia przez Sejm 15 lipca 1961 roku ustawy o rozwoju systemu oświaty. W wielu rozdziałach autor umieścił tabele, w których zawarł zestawienie typów szkól, adresów, specjalizacji, co stanowi cenny materiał porównawczy.

R. Ślęczka w sposób wieloaspektowy scharakteryzował szkolnictwo zawodowe w Krakowie. W siedmiu rozdziałach dokonał kolejno: przeglądu zmian strukturalnych i organizacyjnych tego szkolnictwa, przedstawił sytuacje kadry kierowniczej i nauczycielskiej, scharakteryzował społeczność uczniowska, opisał plany i programy 